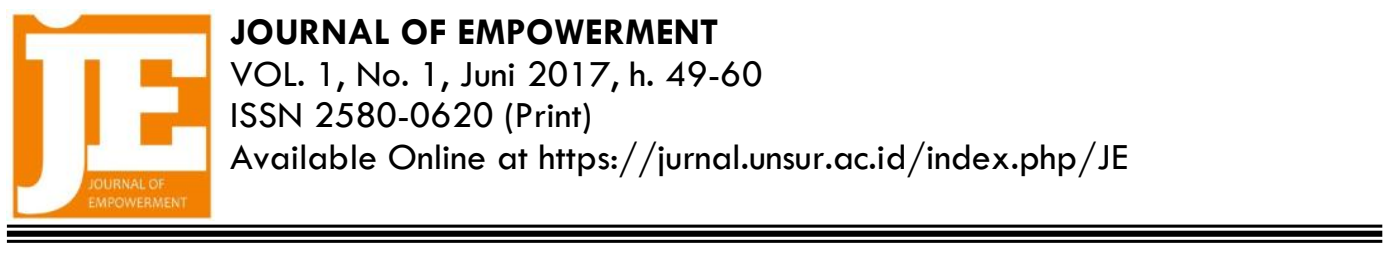

\title{
PENYULUHAN PENDIDIKAN POLITIK BAGI PEMILIH PEMULA GUNA MENINGKATKAN PARTISIPASI HAK PILIH PADA PEMILIHAN GUBERNUR DKI JAKARTA TAHUN 2017
}

(Studi pada Siswa-Siswi Sekolah Menengah Atas Se-Kecamatan Tanjung Priok)

\author{
Amsori \\ Sekolah Tinggi Ilmu Hukum IBLAM Jakarta \\ amsori.sh@gmail.com
}

Masuk : Maret 2017 Penerimaan : Maret $2017 \quad$ Publikasi : Juni 2017

\begin{abstract}
ABSTRAK
Tujuan artikel ini adalah untuk menjelaskan kegiatan penyuluhan pendidikan politik bagi pemilih pemula dalam rangka meningkatkan pemahaman masyarakat pemilih pemula, dalam hal ini diwakili oleh Siswa-siswi Sekolah Menengah Atas di Kecamatan Tanjung Priok. Metode penelitian yang digunakan adalah pendekatan kualitatif. Teknik analisis data dalam penelitian ini menggunakan model deskriptif. Adapun kesimpulan dari artikel ini adalah semua pihak harus dapat mendukung upaya penyelenggara Pemilu dalam hal meningkatkan kualitas proses pemilu; Meningkatkan partisipasi pemilih; Meningkatkan kepercayaan publik terhadap proses demokrasi; dan Membangkitkan kesukarelaan masyarakat sipil dalam agenda pemilu dan demokratisasi.
\end{abstract}

Kata Kunci: Pemilu, Pemilih Pemula, Pendidikan Politik, dan Partisipasi.

ABSTRACT

The purpose of this article is to explain the extension activities of political education for voters in order to improve public understanding of voters, in this case represented by the Students of Senior High School in the district of Tanjung Priok. The method used is a qualitative approach. Data analysis techniques in this study using a descriptive model. The conclusion of this article is all parties must be able to support the efforts of the election organizers in terms of improving the quality of electoral processes; Increase voter participation; Improving public confidence in the democratic process; Generating volunteerism and civil society in the elections and democratization agenda.

Keywords: Elections; Starter Voters; Political Education; and Participation.

A. PENDAhUlUAN

1. Latar Belakang

Pemilihan umum sebagai sarana

demokrasi telah digunakan di sebagian besar negara di dunia termasuk Indonesia. Negara

Kesatuan Republik Indonesia sejak reformasi telah bertekad untuk mewujudkan sistem politik yang demokratis, dengan cara diadakannya pemilihan langsung yang melibatkan warga negaranya untuk ikut serta dalam proses pemberian suara (voting). Pemilihan Presiden, Pemilihan Anggota DPR dan DPRD, Pemilihan Anggota DPD hingga Pemilihan Kepala Daerah juga di laksanakan dengan cara yang demokratis. Di Indonesia sistem ini dikenal dengan nama Pemilihan Umum (pemilu). Pemilu yang dilaksanakan di Indonesia dilakukan 
dengan rentang waktu 5 (lima) tahun sekali dan diselenggarakan oleh suatu komisi pemungutan suara yang independen, dikenal dengan nama Komisi Pemilihan Umum (KPU) sebagai mana tercantum dalam Pasal 1 (ayat 6) Undang-Undang Republik Indonesia Nomor 15 Tahun 2011 tentang Penyelenggara Pemilihan Umum, yang menjelaskan bahwa pemilu diselenggarakan oleh Komisi Pemilihan Umum yang bersifat nasional, tetap dan mandiri. ${ }^{1}$

Secara umum, jenis-jenis pemilih pada pemilihan umum memiliki 4 karakteristik yaitu: pertama pemilih rasional, pemilih dalam hal ini lebih mengutamakan kemampuan partai politik atau calon peserta pemilu dengan program kerjanya, mereka melihat program kerja tersebut melalui kineria partai atau kontestan di masa lampau, dan tawaran program yang ditawarkan sang calon atau partai politik dalam menyelesaikan berbagai permasalahan yang sedang terjadi. Pemilih jenis ini memiliki ciri khas yang tidak mementingkan ikatan ideologi kepada suatu partai politik atau seorang kontestan. Hal yang terpenting bagi pemilih jenis ini adalah apa yang bisa (dan yang telah) dilakukan oleh sebuah partai atau seorang kontestan pemilu. Kedua, pemilih kritis. Jenis pemilih ini, menjadikan nilai ideologis sebagai pijakan untuk menentukan kepada partai atau kontestan pemilu mana mereka akan berpihak dan selanjutnya mereka akan mengkritisi kebijakan yang akan atau yang telah dilakukan. Jenis pemilih seperti ini biasanya tertarik dengan program kerja yang ditawarkan

Hamad, Ibnu, (2004), Konstruksi Realitas Politik dalam Media Massa, Jakarta, Granit, hlm. 2. sebuah partai/kontestan baru kemudian mencoba memahami nilainilai dan faham yang melatarbelakangi pembuatan sebuah kebijakan. Ketiga, pemilih tradisional. Pemilih jenis ini memiliki orientasi ideologi yang sangat tinggi dan tidak terlalu melihat kebijakan partai politik atau seorang kontestan sebagai sesuatu yang penting dalam pengambilan keputusan. Pemilih tradisional sangat mengutamakan kedekatan sosial-budaya, nilai, asalusul, paham dan agama sebagai ukuran untuk memilih sebuah partai politik atau kontestan pemilu. Keempat, pemilih skepsis. Pemilih ini berkeyakinan bahwa siapapun yang menjadi pemenang dalam pemilu, hasilnya sama saja, tidak ada perubahan yang berarti yang dapat terbagi bagi kondisi Daerah/ Negara. ${ }^{2}$

Dalam pelaksanaan Pemilukada Gubernur dan Wakil Gubernur DKI Jakarta. Para pemilih pemula yang kebanyakan dari siswa-siswi Sekolah Menengah Atas serta mahasiswamahasiswi yang baru memasuki usia hak pilih belum memiliki jangkauan politik yang luas untuk menentukan pilihan. Sehingga, terkadang apa yang mereka pilih tidak sesuai dengan apa yang diharapkan. Alasan ini pula yang menyebabkan pemilih pemula sangat rawan untuk didekati dengan pendekatan materi. Partai politik lebih banyak memberdayakan pemilih pemula melalui kampanye dengan

\footnotetext{
Aan Hermawan, Agus, (Desember 2014), Persepsi Pemuda terhadap Partai Politik Nasional Peserta Pemilu 2014 dan Implikasinya terhadap Ketahanan Politik Wilayah (Studi pada KNPI Provinsi Banten), Jurnal Ketahanan Nasional, No XX (3), hlm. 99107.
} 
melibatkan politik uang. ${ }^{3}$ Selain rentan dimanfaatkan partai politik, pemilih pemula juga rentan golput. Kelompok pemilih pemula adalah kelompok yang lebih kritis dibanding kelompok lainnya sehingga berpeluang menjadi golput, karena banyak diantara pemilih pemula bingung untuk menggunakan hak pilih mereka dalam pemilu. ${ }^{4}$ Hingga saat ini belum banyak KPU dan partai politik yang melakukan pendidikan politik serius terhadap pemilih pemula. Pemilih pemula menggantungkan pendidikan politik kepada informasi media massa, sesama teman, orang tua, atau guru di sekolah. ${ }^{5}$ Dalam pemilihan umum gubernur DKI Jakarta tercatat sekitar 7.132.856 DPT akan menggunakan hak pilihnya, dimana 10,07 persen atau 718.571 orang diantaranya tergolong pemilih pemula. KPU DKI Jakarta mengategorikan pemilih pemula pada rentang umur 17-21 tahun. ${ }^{6}$

Secara kuantitas, pemilih pemula memang lebih sedikit dibandingkan dengan pemilih yang lain, tetapi ini merupakan sebuah penggambaran bagaimana partisipasi mereka ke

Ismanto, Dkk, (2004), Pemilihan Presiden Secara Langsung 2004 Dokumentasi, Analisis dan Kritik, Jakarta, Kementerian Riset dan Teknologi, dan Departemen Politik dan Perubahan Sosial CSIS, hlm. 151.

4 Yeni, Fitri, (2011), Partisipasi Politik Pemilih Pemula Dalam Pemilihan Presiden Dan Wakil Presiden 2009 Di Kecamatan Padang Utara Kota Padang, Jurusan Ilmu Sosial Politik Fakultas Ilmu Sosial Universitas Negeri Padang, Skripsi tidak dipublikasikan, hlm. 29.

Hasibuan, dkk, (2008), Revolusi Politik Kaum Muda, Jakarta, Yayasan Obor Indonesia, hlm. 228.

6 Wawancara dengan Betty Epsilon Idroos, Komisioner KPU DKI Jakarta Bidang Sosialisasi, tanggal 14 Januari (2017), di Kantor Kesiswaan SMAN 18 Jakarta, pukul. $13.00-13.45$ WIB. depannya, walaupun secara kuantitas suara dari pemilih pemula tidak dapat mempengaruhi hasil perolehan akhir suara, tetapi tidak bisa dipungkiri bahwa partai politik juga memerlukan suara mereka untuk menambah perolehan suara yang telah ada, sebab tujuan dari partai politik dalam sebuah pemilihan adalah bagaimana memperoleh suara sebanyak-banyaknya pada pemilihan tersebut. $^{7}$

Berdasarkan paparan pada latar belakang di atas, maka ada beberapa masalah terkait partisipasi pemilih pemula diantaranya: 1) masih kurang pahamnya pemilih pemula akan proses pelaksanaan pemilukada sehingga tidak memberikan hak suaranya pada pemilihan kepala daerah. 2) pemilih pemula mudah dipengaruhi oleh kepentingan-kepentingan tertentu, terutama oleh orang terdekat, seperti anggota keluarga mulai dari orang tua hingga kerabat. 3) masih kurangnya minat pemilih pemula untuk mengikuti penjelasanpenjelasan yang diberikan oleh KPU DKI Jakarta selaku penyelenggara untuk merangsang partisipasi pemilih pemula.

\section{Lokasi Pengabdian}

Artikel ini merupakan salah satu bentuk laporan Pengabdian Kepada Masyarakat yang dilakukan pada siswa-siswi SMA se-Kecamatan Tanjung Priok yang bertempat di SMAN 18 Jakarta jalan Warakas 1 Tanjung Priok.

\section{Peserta}

Adapun jumlah peserta pada kegiatan ini yaitu 1.200 siswa-siswi

Arifin, (2010), Peran media Massa dalam bidang sosial dan politik, Yogyakarta, Pustaka Pelajar, hlm. 67. 
yang terdiri dari 21 SMA baik Negeri maupun Swasta di wilayah kecamatan Tanjung Priok. Acara ini diprakarsai oleh Komisi Pemilihan Umum Daerah DKI Jakarta pada tanggal 14 Januari 2017 dengan tema "Penyuluhan Pendidikan Politik Bagi Pemilih Pemula".

\section{B. METODE}

Siswa-siswi dari 21 SMA seKecamatan Tanjung Priok dikumpulkan di SMAN 18 Jakarta untuk mendapatkan penyuluhan tentang pendidikan politik dari Komisi pemilihan Umum.

\section{PEMBAHASAN}

1. Dasar Hukum

Undang-Undang Dasar Republik Indonesia 1945: Pasal 1 ayat (2) dan ayat (3), Pasal 18 ayat (3), Pasal 18 ayat (4), Pasal 19 ayat (1), Pasal 20, Pasal 22C ayat (1) dan ayat (2), Pasal 22E, Pasal 24C ayat (1). Undang-Undang Nomor 2 Tahun 2011 Tentang Partai Politik. UndangUndang Nomor 15 Tahun 2011 Tentang Penyelenggara Pemilihan Umum. Undang-Undang Nomor 8 Tahun 2012 Tentang Pemilihan Umum Anggota Dewan Perwakilan Rakyat, Dewan Perwakilan Daerah, dan Dewan Perwakilan Rakyat Daerah. Undang-Undang Nomor 42 Tahun 2008 tentang Pemilihan Umum Presiden dan Wakil Presiden. Undang-Undang Nomor 8 Tahun 2015 tentang perubahan UndangUndang Nomor 1 Tahun 2015 tentang Pemilihan Umum Kepala Daerah dan Wakil Kepala Daerah. Undang-Undang Nomor 9 Tahun 2015 tentang perubahan UndangUndang Nomor 2 Tahun 2015 tentang Pemerintah Daerah. Peraturan Komisi Pemilihan Umum. Peraturan Badan Pengawas
Pemilihan Umum. Peraturan Dewan Kehormatan Pemilihan Umum. ${ }^{8}$

\section{Asas Pemilihan Umum}

Asas Pemilu berdasarkan asas langsung, umum, bebas, rahasia, jujur, dan adil yang akan diuraikan sebagai berikut: a) Langsung: pemilih mempunyai hak untuk secara langsung memberikan suaranya; b) Umum: berarti pada dasarnya semua warganegara yang memenuhi persyaratan berhak ikut memilih dalam pemilihan umum; c) Bebas: berarti setiap warganegara yang berhak memilih bebas menentukan pilihannya tanpa tekanan dan paksaan dari siapapun; d) Rahasia: berarti dalam memberikan suaranya, pemilih dijamin bahwa pilihannya tidak akan diketahui oleh pihak manapun dan dengan jalan apapun; e) Jujur: berarti dalam menyelenggarakan pemilihan umum; penyelenggaraan/ pelaksana, pemerintah dan partai politik peserta Pemilu, pengawas dan pemantau Pemilu, termasuk pemilih, serta semua pihak yang terlibat secara tidak langsung, harus bersikap dan bertindak jujur sesuai dengan peraturan perundangan yang berlaku; dan f) Adil: setiap pemilih dan peserta Pemilu mendapat perlakuan yang sama, serta bebas dari kecurangan pihak manapun. ${ }^{9}$

3. Asas Penyelenggaraan Pemilu Mandiri, Jujur, Adil, Kepastian Hukum, Tertib Penyelenggaraan, Kepentingan Umum, Keterbukaan,

\footnotetext{
Sekretariat Jendral KPU Biro Teknis dan Humas, (2010), Modul Pemilih Untuk Pemula, Jakarta, KPU Vol. 1 No. 260.

Surandajang, (2013), Pilkada Langsung, Jakarta, Kata penerbit, hlm. 8 .
} 
Proporsional, Akuntabilitas, Efisiensi, Efektivitas.

4. Jenis-Jenis Pemilihan Umum

a. Pemilu DPR, DPD dan DPRD Provinsi serta DPRD Kabupaten/ Kota;

b. Pemilu Presiden dan Wakil Presiden;

c. Pemilu Kepala Daerah (Gubernur dan Wakil Gubernur, Bupati dan Wakil Bupati, Walikota dan Wakil Walikota).

\section{Peserta Pemilihan Umum}

a. Pemilu DPR, DPRD Provinsi dan DPRD Kabupaten/Kota adalah Partai Politik, dengan pengaturan jumlah terpilih sesuai daerah pemilihan;

b. Pemilu DPD adalah perorangan untuk daerah pemilihan Provinsi dengan kursi setiap provinsi adalah 4 (empat) calon terpilih sebagaimana diatur dengan undang-undang;

c. Pemilu Presiden dan Wakil Presiden adalah Pasangan Calon yang diusulkan oleh Partai Politik/gabungan partai politik sesuai ketentuan perundangundangan;

d. Peserta Pemilu Kepala Daerah (Gubernur dan Wakil Gubernur, Bupati dan Wakil Bupati, Walikota dan Wakil Walikota) adalah Pasangan Calon yang diusulkan oleh Partai

e. Politik/gabungan partai politik atau perseorangan sesuai ketentuan perundang-undangan.

\section{Pemilih}

Syarat Pemilih dalam Pemilihan Umum secara umum diatur sebagai berikut: WNI, telah genap berusia 17 (tujuh belas) tahun atau lebih atau sudah/pernah kawin, terdaftar sebagai pemilih, tidak sedang terganggu jiwa/ingatannya, tidak sedang dicabut hak pilinnya berdasarkan keputusan pengadilan yang telah mempunyai hukum tetap, bukan anggota TNI/Polri.

7. Pemilih yang Berhak
Memberikan Suara
a. Pemilih yang terdaftar dalam
DPT di TPS;
b. Pemilih yang terdaftar dalam
DPTb;
c. Pemilih yang tidak terdaftar
dalam DPT dan DPTb: Pemilih
Khusus yang terdaftar dalam
DPK; Pemilih Khusus Tambahan
DPKTb;
d. Pemilih yang menggunakan hak pilih dengan menggunakan KTP dan Kartu Keluarga (KK) atau sebutan lain (Sesuai dengan keputusan MK 85/2012).

\section{Ketentuan dalam Penggunaan Hak Pilih}

a. Pemilih terdaftar dalam DPT menggunakan hak pilih sesuai dengan tempat pemilih terdaftar (Normal);

b. Pindah Memilih:

1) Melapor kepada PPS asal untuk mendapatkan surat pemberitahuan DPTb untuk digunakan untuk memilih di TPS lain dengan menunjukkan KTP atau identitas yang sah, oleh PPS asal dicoret dalam DPT;

2) Pemilih melapor ke PPS tujuan paling lambat 3 (tiga) hari sebelum Tanggal Pemungutan Suara dengan menunjukkan KTP atau identitas lain yang sah dan membawa Formulir yang ditandatangani oleh PPS asal;

3) Dalam hal Pemilih tidak sempat melaporkan diri 
kepada PPS tujuan, tetapi mempunyai Formulir "pengantar" dari PPS asal, dapat memberikan suara pada Tanggal Pemungutan Suara;

c. Memilih dengan menggunakan KTP dan Kartu Keluarga (KK) atau sebutan lain sesuai dengan ketentuan peraturan KPU;

d. Pemilih dengan halangan fisik dapat dibantu oleh pendamping yaitu Anggota KPPS atau orang lain atas permintaan. Pemilih tunanetra dapat menggunakan alat bantu tunanetra dan pendamping pemilih menandatangani surat pernyataan dengan menggunakan Formulir khusus. ${ }^{10}$

\section{Pelaksanaan Pemilihan Umum a. Kampanye}

Kampanye Pemilu adalah masa di mana peserta pemilu menyampaikan visi, misi dan program untuk mendulang suara sebanyakbanyaknya dari pemilih. Kampanye Pemilu dapat dilakukan dengan metode: pertemuan terbatas; pertemuan tatap muka; penyebaran bahan Kampanye Pemilu kepada umum; pemasangan alat peraga di tempat umum; iklan media massa cetak dan media massa elektronik; rapat umum; dan kegiatan lain yang tidak melanggar larangan Kampanye Pemilu dan ketentuan peraturan perundang-undangan.

\section{b. Visi, Misi, dan Program Peserta Pemilu}

Visi misi dan program peserta Pemilu harus dicermati secara komprehensif.

1) Visi adalah rangkaian kalimat yang menyatakan cita-cita atau

10 Supono, Sapto, (2005), Penyimpangan Pilkada, Bandung, Pustaka Sinar Harapan, hlm. 93-96. impian sebuah organisasi, perusahaan, atau individu yang ingin dicapai di masa depan. Dalam konteks pemilu, visi peserta pemilu merupakan hal yang sangat penting, dikarenakan, visi mengandung nilai-nilai, aspirasi serta kebutuhan di masa depan. Visi antara lain harus mengandung karakteristik seperti, dapat di bayangkan, menarik, realistis dan dapat dicapai, jelas, aspiratif dan responsif terhadap perubahan lingkungan, serta mudah dipahami;

2) Misi merupakan lanjutan dari visi yang pada dasarnya adalah alasan mendasar eksistensi dari suatu organisasi. Misi biasanya sudah mengarah secara tegas menuju suatu tujuan yang secara teknis dapat dijabarkan ke dalam program-program. Hubungan visi, misi dan program tersebut fokus perhatian para pemilih dan masyarakat dalam melihat kapabilitas peserta Pemilu. Jika misi tidak jelas, maka sudah dapat dipastikan programnya juga perlu dipertanyakan;

3) Program merupakan penerjemahan secara teknis dari visi dan misi, para pemilih dan masyarakat harus cerdas dan cermat menilai program yang ditawarkan: realistis sesuai dengan kemampuan peserta pemilu, menyentuh persoalanpersoalan yang dihadapi para pemilih dan masyarakat, dirancang dengan pemikiran yang komprehensif dll. Kesalahan menilai programprogram tersebut akan menimbulkan kesalahan dalam menentukan pilihan. Kesalahan menentukan pilihan akan 


\begin{abstract}
mengakibatkan terpilihnya orang-orang yang tidak tepat untuk mengemban tugas-tugas kenegaraan dan pemerintahan. Kesadaran pemilih dalam mencermati menjadi kunci utama terpilihnya para wakil rakyat dan pemimpin pemerintahan yang benar-benar dapat menyelesaikan persoalan yang ada di masyarakat. Kesadaran inilah yang seharusnya terus dibangun, sehingga Pemilu sebagai instrumen pelaksanaan demokrasi benar-benar bermakna bagi perbaikan kehidupan berbangsa dan bernegara. ${ }^{11}$
\end{abstract}

\section{c. Setelah Menilai, Tentukan Pilihan Terbaik}

Setelah para pemilih memiliki informasi yang cukup dan dapat mendiskusikan informasi dan data itu dengan elemen yang ada di masyarakat, sehingga dapat memperkaya informasi dan menjadi dasar yang kuat dalam menentukan pilihan. Rasionalitas diperlukan dalam menentukan pilihan, apakah peserta pemilu dan calon yang akan dipilih benar-benar menawarkan program yang sesuai dengan kebutuhan masyarakat dan secara personal calon merupakan sosok yang dapat dipercaya.

\section{d. Pastikan Memberikan Suara dengan Benar}

1) Surat Suara Pemilu Presiden dan Wakil Presiden, Pemilu Gubernur dan Wakil Gubernur serta Pemilu Bupati dan wakil Bupati/

11 Sukriono, Didik, (Juni 2009), Menggagas Sistem Pemilihan Umum di Indonesia, Jurnal Konstitusi Pusat Kajian Konstitusi, Volume II No. 1, Universitas Kanjuruhan Malang, hlm. 72 86

\section{Walikota dan Wakil Walikota terdapat nomor urut, nama dan Foto Pasangan Calon; \\ 2) Pemilih dapat melihat Daftar Calon Tetap pada papan yang ada di TPS.}

\section{e. Mekanisme Pemberian Suara}

Pemberian suara pada Pemilu tahun 2014, dengan cara mencoblos seperti diatur dalam UndangUndang No. 8 Tahun 2012 dan Undang-undang Nomor 42 Tahun 2008: Mekanisme pemberian suara pada TPS:

1) Pemilih menerima pemberitahuan;

2) Pemilih datang ke TPS, menyerahkan surat pemberitahuan kepada petugas KPPS;

3) Petugas KPPS mengecek kesesuaian nama dalam surat pemberitahuan;

4) Pemilih dipanggil oleh ketua KPPS, kemudian menerima surat suara;

5) Pemilih membuka surat suara lebar-lebar di depan ketua KPPS untuk memastikan tidak rusak, yang dapat mengakibatkan surat suara menjadi tidak sah;

6) Apabila surat suara dipastikan rusak, Pemilih dapat meminta penggantian surat suara, dan ketua KPPS wajib memberikan penggantian surat suara yang rusak;

7) Apabila surat suara tersebut dalam keadaan baik maka pemilih menuju bilik suara untuk memberikan suaranya;

8) Pemilih melipat kembali surat suara untuk dimasukkan ke dalam kotak suara;

9) Pemilih menandai jarinya dengan tinta yang menandakan 
bahwa pemilih sudah memberikan hak suaranya.

10. Pemungutan dan Penghitungan Suara Berlangsung Jujur dan Adil

a. Hak Pemilih

1) Warga masyarakat melalui saksi partai politik, atau saksi pasangan atau saksi perseorangan, dapat mengajukan keberatan terhadap jalannya pemungutan dan penghitungan suara oleh KPPS apabila terdapat hal-hal yang tidak sesuai dengan peraturan perundang-undangan;

2) Dalam hal tidak terdapat saksi partai politik, atau saksi perseorangan, warga masyarakat dapat mencatat pelanggaran tersebut dan melaporkannya kepada Panitia Pengawas Pemilu disertai buktibukti pendukung;

3) Pemilih menyampaikan keberatan melalui saksi partai politik atau saksi pasangan calon atau saksi perseorangan, dalam hal keberatan yang diajukan dapat diterima, KPPS seketika itu juga mengadakan pembetulan;

4) Keberatan saksi partai politik peserta Pemilu dan perseorangan dicatat dengan menggunakan formulir yang telah disediakan;

5) Keberatan yang diajukan terhadap proses penghitungan suara di TPS tidak menghalangi proses penghitungan suara di TPS;

6) Pemilih dilarang mengganggu proses penghitungan suara di TPS.

\section{b. Hak Pemilih Melakukan Monitoring Rekapitulasi Hasil Penghitungan Suara}

Prinsip utama dari proses rekapitulasi ini adalah:

1) Pelaksanaan rekapitulasi hasil penghitungan suara dilaksanakan secara transparan;

2) Pelaksanaan tersebut memberikan akses seluas-luasnya bagi peserta Pemilu untuk melakukan koreksi.

\section{Penetapan Pemenang Peserta Pemilihan Umum}

Perolehan kursi Partai Politik ditetapkan oleh KPU sesuai dengan tingkatannya:

a. Pemilu DPR, DPD, dan DPRD

1) Partai Politik Peserta Pemilu harus memenuhi ambang batas perolehan suara sekurangkurangnya 3,5\% dari jumlah suara sah secara nasional untuk diikutkan dalam penentuan perolehan kursi anggota DPR;

2) Bilangan Pembagi Pemilih (BPP) $D P R$, diperoleh dari pembagian jumlah suara sah seluruh Partai Politik Peserta Pemilu yang memenuhi ambang batas dengan jumlah kursi di suatu daerah pemilihan untuk menentukan jumlah perolehan kursi;

3) BPP DPRD, adalah bilangan yang diperoleh dari pembagian jumlah suara sah dengan jumlah kursi di suatu daerah pemilihan untuk menentukan jumlah perolehan kursi Partai Politik Peserta Pemilu dan anggota DPRD provinsi dan DPRD kabupaten/kota.

Setelah diperoleh angka BPP, ditetapkan perolehan jumlah kursi tiap untuk Calon Anggota DPR dan DPRD Parpol Peserta Pemilu di suatu 
daerah pemilihan, dengan ketentuan berikut:

1) Apabila jumlah suara sah suatu Parpol sama dengan atau lebih besar dari BPP, dalam penghitungan tahap pertama diperoleh sejumlah kursi dengan kemungkinan sisa suara yang akan dihitung pada tahap kedua;

2) Apabila jumlah suara sah suatu Parpol Peserta Pemilu lebih kecil daripada BPP, maka dalam penghitungan tahap pertama tidak diperoleh kursi, dan jumlah suara sah tersebut dikategorikan sebagai sisa suara yang akan dihitung dalam penghitungan tahap kedua dalam hal masih terdapat sisa kursi;

3) Penghitungan perolehan kursi tahap kedua dilakukan apabila masih terdapat sisa kursi yang belum terbagi dalam penghitungan tahap pertama, dengan cara membagikan jumlah sisa kursi yang belum terbagi kepada Partai Politik Peserta Pemilu satu demi satu berturut-turut sampai habis, dimulai dari Partai Politik Peserta Pemilu yang mempunyai sisa suara terbanyak.

b. Penetapan Calon Terpilih

$\begin{array}{lll}\text { Penetapan Calon } & \text { terpilih } \\ \text { dilaksanakan oleh KPU sesuai }\end{array}$
tingkatannya.

1) Penetapan calon terpilih anggota DPR, DPRD provinsi, dan DPRD Kabupaten/Kota:

a) Penetapan calon terpilih dari didasarkan pada perolehan kursi di suatu daerah pemilihan dengan ketentuan berdasarkan calon suara terbanyak;

b) Apabila terdapat 2 (dua) atau lebih Calon Anggota memperoleh Suara Sah yang sama di suatu daerah pemilihan, maka ditetapkan berdasarkan jumlah dukungan suara yang lebih banyak persebarannya;

c) Apabila 2 (dua) calon berjenis kelamin berbeda, perempuan dan laki-laki memperoleh Suara Sah yang sama di suatu daerah pemilihan, maka calon perempuan ditetapkan sebagai nama calon terpilih Anggota DPR;

d) Apabila 2 (dua) calon berjenis kelamin sama, perempuan dengan perempuan atau laki-laki dengan laki-laki memperoleh Suara Sah yang sama di suatu daerah pemilihan, maka berdasarkan jumlah dukungan suara yang lebih banyak persebarannya.

e) Dalam hal persebaran dukungan suara untuk calon sebagaimana dimaksud pada angka (4) persebarannya masih sama, penetapan dengan melihat persebaran perolehan suara pada 1 (satu) tingkat di bawahnya.

2) Penetapan calon terpilih anggota DPD:

a) Didasarkan pada nama calon yang memperoleh suara terbanyak pertama, kedua, ketiga, dan keempat di provinsi yang bersangkutan;

b) Dalam hal perolehan suara calon terpilih keempat terdapat jumlah suara yang sama, calon dengan dukungan Pemilih yang lebih merata penyebarannya di seluruh kabupaten/kota di provinsi tersebut ditetapkan sebagai calon terpilih. 
3) Penetapan calon terpilih Presiden dan Wakil Presiden.

Pasangan calon terpilih adalah pasangan calon yang memperoleh suara lebih dari $50 \%$ dari jumlah suara dengan sedikitnya $20 \%$ suara di setiap provinsi yang tersebar di lebih dari 50\% jumlah provinsi di Indonesia. Dalam hal tidak ada pasangan calon yang perolehan suaranya memenuhi persyaratan tersebut, 2 pasangan calon yang memperoleh suara terbanyak pertama dan kedua dipilih kembali dalam pemilihan umum (putaran kedua). Dikarenakan untuk Pilpres 2014 diikuti 2 (dua) pasangan calon, pemenang pemilu adalah dengan perolehan suara terbanyak.

4) Penetapan calon terpilih Kepala Daerah.

Sesuai dengan Undang Undang Nomor 8 Tahun 2015 Tentang Perubahan Undang Undang Nomor 1 Tahun 2015 tentang Pemilihan Umum Kepala Daerah dan Wakil Kepala Daerah, bahwa terpilih ditentukan dengan suara Pasangan calon dengan jumlah terbanyak (Pasal 107 Ayat (1) dan Pasal 109 Ayat (1).

\section{PENUTUP}

\section{Kesimpulan}

Dalam meningkatkan partisipasi hak pilih pemilih pemula diperlukan Informasi yang lebih komprehensif melalui pendidikan politik di sekolah. Meskipun memiliki informasi politik memadai, sebagian pemilih pemula masih dipengaruhi ikatan emosional dan komersial dalam menentukan pilihan politiknya. Kecenderungan irasional dari pemilih pemula ini hendaknya dapat dihindari melalui pendidikan politik yang secara intensif dilakukan pemerintah melalui KPU dan partai politik. Pemerintah tidak bisa melepaskan tanggung jawab pelaksanaan pendidikan politik kepada LSM. Partai politik pun harus mampu membuktikan komitmennya kepada pemilih pemula hingga pemilih pemula tidak enggan berpartisipasi dalam kehidupan politik dan kenegaraan.

\section{Saran}

Penyuluhan politik harus berbentuk program yang memuat kebutuhan dasar pemilih pemula berupa pembentukan pola pikir dengan basis rasionalitas untuk mempertimbangkan keputusan memilih atas dasar kemampuan, visi-misi dan track record dari partai-partai dan para kandidat. Selain itu diperlukan penanaman kecakapan partisipatoris pemilih pemula agar pemilih pemula dapat berpartisipasi dengan dibekali pengetahuan dan nilai-nilai yang diperlukan sebagai insan politik.

Tanggungjawab mencerdaskan pemilih pemula ini tidak hanya tanggungjawab dari stakeholder tetapi juga para elemen masyarakat seperti LSM, keluarga pemilih pemula, dan penyelenggara pemilu. Bagi LSM hendaknya sosialisasi politik bagi pemilih pemula tidak secara insidental agar efektif; bagi keluarga agar terbuka terhadap kondisi politik yang ada; bagi masyarakat agar memiliki data pemilih pemula agar dilibatkan dalam proses pemilu; bagi sekolah agar aktif bekerja sama dengan penyelenggara pemilu ataupun LSM untuk dapat mensosialisasikan pemilu pada pemilih pemula sekaligus memberikan kecakapan partisipatoris; bagi partai politik yang memiliki fungsi sebagai sarana komunikasi politik hendaklah dapat 
memilah posisinya antara kepentingan politik dan pendidikan politik dalam menjalankan fungsinya tersebut, bagi mahasiswa sosiologi khususnya sebagai golongan akademis agar dapat memanfaatkan program Kuliah Kerja Nyata dalam memberikan sosialisasi politik kepada masyarakat agar masyarakat tidak hanya sekedar melek politik namun juga cakap politik.

\section{UCAPAN TERIMA KASIH}

Penulis ucapkan banyak terima kasih kepada KPUD DKI Jakarta yang telah memberikan dukungan kepada penulis untuk senantiasa mengabdi kepada masyarakat. Penulis juga mengucapkan terima kasih kepada STIH IBLAM Jakarta atas dukungan dan fasilitas administrasi yang telah diberikan.

\section{DAFTAR PUSTAKA}

\section{A. Buku}

Arifin, (2010), Peran media Massa dalam bidang sosial dan politik, Yogyakarta, pustaka pelajar.

Hamad, Ibnu, (2004), Konstruksi Realitas Politik dalam Media Massa, Jakarta, Granit.

Hasibuan, dkk, (2008), Revolusi Politik Kaum Muda, Jakarta, Yayasan Obor Indonesia.

Ismanto, Dkk, (2004), Pemilihan Presiden Secara Langsung 2004 Dokumentasi, Analisis dan Kritik, Jakarta, Kementerian Riset dan Teknologi, dan Departemen Politik dan Perubahan Sosial CSIS.
Miles, B. Matthew., Huberman, A. Michael, (2006), Qualitative Data Analysis, A Sourcebook of New Methods, California, SAGE Publication Inc.

Riswandi, (2009), Komunikasi Politik, Yogyakarta, Graha Ilmu.

Sekretariat Jendral KPU Biro Teknis dan Humas, (2010), Modul Pemilih UNTUK Pemula, Jakarta, KPU Volume 1 Nomor 260.

Sugiyono, (2012), Memahami Penelitian Kualitatif, Bandung, Alfabeta.

$$
\begin{aligned}
& \text { Supono, Sapto, (2005), } \\
& \text { Penyimpangan Pilkada, } \\
& \text { Bandung, Pustaka Sinar } \\
& \text { Harapan. }
\end{aligned}
$$

\section{B. Jurnal}

Aan Hermawan, Agus, (Desember 2014), Persepsi Pemuda terhadap Partai Politik Nasional Peserta Pemilu 2014 dan Implikasinya terhadap Ketahanan Politik Wilayah (Studi pada KNPI Provinsi Banten), Jurnal Ketahanan Nasional, No XX (3)

Sukriono, Didik, (Juni 2009),
Menggagas Sistem Pemilihan
Umum di Indonesia, Jurnal
Konstitusi
Konstitusi, Pusat Kajian
Kanjuruhan Malang, Volume II
No. 1.




\section{Makalah, Skripsi, Tesis, atau Disertasi}

Yeni, Fitri, (2011), Partisipasi Politik Pemilih Pemula Dalam Pemilihan Presiden dan Wakil Presiden 2009 di Kecamatan Padang Utara Kota Padang, Jurusan Ilmu Sosial Politik Fakultas IImu Sosial Universitas Negeri Padang, Skripsi tidak dipublikasikan.

\section{Hasil Wawancara}

Wawancara dengan Betty Epsilon
Idroos, Komisioner KPU DKI
Jakarta Bidang Sosialisasi,
tanggal 14 Januari 2017, di
Kantor Kesiswaan SMAN 18
Jakarta, pukul. 13.00 - 13.45
WIB.

